\title{
A Facile Cathode Design Combining Ni-rich Layered Oxides with Li-rich Layered Oxides for Lithium-ion Batteries
}

\author{
Bohang Song, ${ }^{a}$ Wangda Li, ${ }^{\text {a }}$ Pengfei Yan, ${ }^{b}$ Seung-Min Oh, ${ }^{a}$ Chong-Min Wang, ${ }^{b}$ and Arumugam \\ Manthiram*a \\ ${ }^{a}$ Materials Science and Engineering Program \& Texas Materials Institute, The University of Texas at \\ Austin, Austin, Texas 78712, USA. \\ ${ }^{b}$ Environmental Molecular Science Laboratory, Pacific Northwest National Laboratory, 902 Battelle \\ Boulevard, Richland, Washington 99352, USA. \\ *Corresponding author: E-mail: manth@austin.utexas.edu
}

\begin{abstract}
A facile synthesis method has been developed to prepare $x \mathrm{Li}_{2} \mathrm{MnO}_{3} \cdot(1-x) \mathrm{LiNi}_{0.7} \mathrm{Co}_{0.15} \mathrm{Mn}_{0.15} \mathrm{O}_{2}(x=0,0.03$, $0.07,0.10,0.20$, and 0.30 ) cathode materials, combining the advantages of the high specific capacity of the Ni-rich layered phase and the surface chemical stability of the Li-rich layered phase. X-ray diffraction (XRD), transmission electron microscopy (TEM), and electrochemical charge/discharge measurements confirm the formation of a Li-rich layered phase with $\mathrm{C} 2 / \mathrm{m}$ symmetry. The high-angle annular dark-field (HAADF) scanning transmission electron microscopy (STEM) reveals a spatial relationship that the Li-rich nano-domain islands are integrated into the conventional Ni-rich layered matrix (R3 ). Most importantly, this is the first time that Li-rich phase has been directly observed inside a particle at the nano-scale, when the overall composition of the layered oxide $\mathrm{Li}_{1+\delta} \mathrm{Ni}_{1-\mathrm{y}-\mathrm{z}-\delta} \mathrm{Mn}_{y} \mathrm{M}_{z} \mathrm{O}_{2}(\mathrm{M}=$ metal) is Ni-rich (> 0.5) rather than Mn-rich (> 0.5). Remarkably, the $\mathrm{xLi}_{2} \mathrm{MnO}_{3} \cdot(1-\mathrm{x}) \mathrm{LiNi}_{0.7} \mathrm{Co}_{0.15} \mathrm{Mn}_{0.15} \mathrm{O}_{2}$ cathodes with optimized $x$ value shows superior electrochemical performance at $C / 3$ rate: an initial capacity of $190 \mathrm{~mA}$ $\mathrm{h} \mathrm{g}^{-1}$ with $90 \%$ capacity retention after 400 cycles in a half cell and $73.5 \%$ capacity retention after 900 cycles in a pouch-type full cell.
\end{abstract}

\section{Keywords}

Nickel-rich layered oxide, Lithium-rich layered oxide, surface chemical stability, pouch-type full cell 


\section{Introduction}

The demand for high-energy-density power sources is rapidly increasing for applications ranging from small portable electronic devices to large systems such as electric vehicles and smart grids. Currently, the highest energy density provided by the state-of-the-art commercial lithium-ion batteries is $\sim 160 \mathrm{~W} \cdot \mathrm{h} \mathrm{kg}^{-1}$. Therefore, new electrode materials capable of delivering higher energy densities with long cycle life and better thermal stability are necessary for next-generation batteries. Among the known cathode candidates, the layered structure generally offers high theoretical $\left(\sim 270 \mathrm{~mA} \mathrm{~h} \mathrm{~g}{ }^{-1}\right)$ compared to the other competitors such as spinel $\left(140 \mathrm{~mA} \mathrm{~h} \mathrm{~g}^{-1}\right)$ and olivine $\left(170 \mathrm{~mA} \mathrm{~h} \mathrm{~g}^{-1}\right)$ systems.[1, 2] Unfortunately, only 50\% of $\mathrm{Li}^{+}$ions could be reversibly extracted from the currently used layered $\mathrm{Li}_{1-\mathrm{x}} \mathrm{CoO}_{2}$, resulting in a reduction in the energy density of the commercialized $\mathrm{LiCoO}_{2} /$ graphite cells.

To explore an alternative, the co-substitution of $\mathrm{Ni}$ and $\mathrm{Mn}$ at the $\mathrm{Co}$ sites in $\mathrm{LiCoO}_{2}$ produces a family of $\mathrm{LiCO}_{1-\mathrm{y}-\mathrm{Z}} \mathrm{Ni}_{\mathrm{y}} \mathrm{Mn}_{z} \mathrm{O}_{2}$ cathodes. The three ions play different roles in determination of the electrochemical properties of $\mathrm{LiCO}_{1-y-2} \mathrm{Ni}_{y} \mathrm{Mn}_{2} \mathrm{O}_{2}: \mathrm{Ni}$ as an electron supplier, Co for sustaining an ordering of layered structure, and $\mathrm{Mn}$ for good chemical stability.[3] In this regard, Ni-rich layered oxides $\mathrm{LiNi}_{1-\mathrm{y}-\mathrm{z}} \mathrm{Mn}_{\mathrm{y}} \mathrm{Co}_{z} \mathrm{O}_{2}$ with $\mathrm{Ni}$ content $(1-\mathrm{y}-\mathrm{z})>0.5$ is drawing worldwide interest in recent years.[4-9] Sun's group[10] has summarized the different roles of $\mathrm{Ni}, \mathrm{Co}$, and $\mathrm{Mn}$ in the $\mathrm{LiNi}_{1-\mathrm{y}-\mathrm{z}} \mathrm{Mn}_{\mathrm{y}} \mathrm{Co}_{z} \mathrm{O}_{2}$ system when $\mathrm{Ni}$ content exceeds $1 / 3$, in terms of specific capacity, cycle life, and thermal stability. It is important to note that although the $\mathrm{Ni}$-rich cathodes are capable of delivering a $180-210 \mathrm{~mA} \mathrm{~h} \mathrm{~g}{ }^{-1}$ capacity when $0.6<\mathrm{x}<0.9$, the capacity retention and thermal stability are sacrificed with increasing $\mathrm{Ni}$ content. Poor capacity retention is believed to be associated with undesirable side reactions between the tetravalent transition metal ions, in particular $\mathrm{Ni}^{4+}$, and the electrolyte[11, 12] and phase transition from layered to rock-salt structure $(\mathrm{NiO})$ at particle's surface,[13] both of which cause a substantial decline in the lithiation kinetics at the electrodeelectrolyte interphase. On the other hand, poor thermal stability arises due to the release of oxygen from the crystal lattice at the highly delithiated state. $[8,14]$ Finding out the most suitable composition to meet the industry demands for overall performance remains a challenge to battery researchers. 
As for another family of promising cathode candidates, the Li-rich layered oxides, denoted as $\mathrm{xLi}_{2} \mathrm{MnO}_{3} \cdot(1-\mathrm{x}) \mathrm{LiNi}_{\mathrm{a}} \mathrm{Co}_{\mathrm{b}} \mathrm{Mn}_{\mathrm{c}} \mathrm{O}_{2}(\mathrm{a}+\mathrm{b}+\mathrm{c}=1)$ have also gained extensive attention due to their even higher reversible capacities of more than $250 \mathrm{~mA} \mathrm{~h} \mathrm{~g}^{-1} \cdot[15,16]$ One of the signatures for these materials is that $\mathrm{Li}^{+}$ ions partially reside at the transition-metal layer sites in the local lattice, where the $\mathrm{Mn}^{4+}$-rich environment around the $\mathrm{Li}^{+}$ions form a supperlattice arrangement with a special $\mathrm{C} 2 / \mathrm{m}$ symmetry. Upon charging, $\mathrm{Li}^{+}$ ion extraction involves a release of oxygen from the lattice, leading to structural instability and inevitable rearrangement of residual $\mathrm{Li}^{+}$and transition-metal ions to form a thermodynamically-favorable spinel phase.[17-19] The layered to spinel transformation causes a voltage decay, resulting in a gradual loss of output energy density upon cycling. The voltage decay is recognized as the main issue hindering the practical application of the Li-rich layered oxide cathodes. Although spinel transformation is inevitable, the Li-rich layered oxide cathodes commonly show enhanced cyclability even though the charge cut-off voltage is relatively high ( $\sim .6 \mathrm{~V})$. Such enhanced cyclability is ascribed to the less reactivity of $\mathrm{Mn}{ }^{4+}$ with the electrolyte that minimizes the decline of lithiation kinetics at the electrode-electrolyte interphase and the less formation of Jahn-Teller $\mathrm{Mn}^{3+}$ ions in the host lattice.[20, 21] In summary, the Ni-rich layered oxides deliver stable voltage profile with reasonable specific capacity but suffer from surface chemical instability, whereas the Li-rich layered oxides exhibit reasonably good surface chemical stability but suffer from voltage-decay upon cycling.

Inspired by the individual advantages and disadvantages of the Ni-rich and Li-rich layered oxide cathodes, here we report a novel $x \mathrm{Li}_{2} \mathrm{MnO}_{3} \cdot(1-\mathrm{x}) \mathrm{LiNi}_{0.7} \mathrm{Co}_{0.15} \mathrm{Mn}_{0.15} \mathrm{O}_{2}(\mathrm{x}=0,0.03,0.07,0.10,0.20$, and 0.30 as molar ratio) layered oxide cathodes prepared by a facile method. The idea is to integrate a small amount of Li-rich phase into the Ni-rich phase to stabilize the Ni-rich phase from chemical corrosion, while avoiding the use of a large amount of Li-rich phase minimizes the voltage decay effect. As a result, the modified cathode materials show superior electrochemical performance compared to the conventional Nirich layered $\mathrm{LiNi}_{0.7} \mathrm{Co}_{0.15} \mathrm{Mn}_{0.15} \mathrm{O}_{2}$ oxide both at room and elevated temperatures. Li et al.[9] recently reported the synthesis of a core-shell structure with a Ni-rich composition as a core and a Li-rich composition as a shell to improve the performance. Choi et al.[22] also reported a smart compositional design of $(1-x) \mathrm{Li}\left(\mathrm{Ni}_{0.95} \mathrm{Co}_{0.05}\right) \mathrm{O}_{2} \cdot \mathrm{Li}_{2} \mathrm{MnO}_{3}(\mathrm{x}=0.05$ and 0.1$)$ to achieve Li-rich features inside the $\mathrm{Ni}-\mathrm{rich}$ 
particles. Here in our case, for the first time, structural investigation with high-angle annular dark-field (HAADF) scanning transmission electron microscopy (STEM) shows a clear evidence of $\mathrm{C} 2 / \mathrm{m}$ nanodomains embedded in the 3 lattice for such high-Ni content layered oxides.

\section{Experimental}

\subsection{Synthesis of $\mathrm{xLi}_{2} \mathrm{MnO}_{3} \cdot(1-\mathrm{x}) \mathrm{LiNi}_{0.7} \mathrm{Co}_{0.15} \mathrm{Mn}_{0.15} \mathrm{O}_{2}$}

$\mathrm{Ni}_{0.7} \mathrm{Co}_{0.15} \mathrm{Mn}_{0.15}(\mathrm{OH})_{2}$ precursor was prepared by a transition-metal hydroxide co-precipitation method with a continuous stirring tank reactor (CSTR). Prior to the precipitation reaction, a desired amount of saturated $\mathrm{NH}_{4} \mathrm{OH}$ was added to the CSTR for the establishment of the initial condition. Subsequently, a metal solution containing $\mathrm{NiSO}_{4} \cdot 6 \mathrm{H}_{2} \mathrm{O}, \mathrm{CoSO}_{4} 7 \mathrm{H}_{2} \mathrm{O}$, and $\mathrm{MnSO}_{4} \mathrm{H}_{2} \mathrm{O}$ with a molar ratio of $70: 15: 15$ at a combined concentration of $1.0 \mathrm{M}$ was fed into the CSTR at a controlled rate. In the meantime, $2.0-4.0 \mathrm{M}$ $\mathrm{KOH}$ aqueous solution with $\mathrm{NH}_{4} \mathrm{OH}$ was pumped separately into the CSTR to maintain the $\mathrm{pH}$ value within the appropriate range $(\sim 11)$ during the reaction, along with $\mathrm{N}_{2}$ as a protective gas. Throughout the coprecipitation process, the amount of $\mathrm{NH}_{4} \mathrm{OH}$ added and the temperature $\left(50{ }^{\circ} \mathrm{C}\right)$ were also carefully monitored and controlled. After filtering, washing, and drying at around $100{ }^{\circ} \mathrm{C}$ under vacuum overnight, the as-synthesized precursor particles were collected. To prepare the various $\mathrm{xLi}_{2} \mathrm{MnO}_{3} \cdot(1-$ $\mathrm{x}) \mathrm{LiNi}_{0.7} \mathrm{Co}_{0.15} \mathrm{Mn}_{0.15} \mathrm{O}_{2}(\mathrm{x}=0,0.03,0.07,0.10,0.20$, and 0.30 as molar ratios) samples, $2 \mathrm{~g}$ of the $\mathrm{Ni}_{0.7} \mathrm{Co}_{0.15} \mathrm{Mn}_{0.15}(\mathrm{OH})_{2}$ precursor was mixed and ground with a certain amount of $\mathrm{MnCO}_{3}$ (calculated based on the required amount of $\mathrm{Li}_{2} \mathrm{MnO}_{3}$ ) and corresponding amount of $\mathrm{LiOH} \cdot \mathrm{H}_{2} \mathrm{O}$ (with $3 \%$ excess) for $10 \mathrm{~min}$. Subsequently, the mixture was preheated at $500^{\circ} \mathrm{C}$ for $12 \mathrm{~h}$ before heating up to $800{ }^{\circ} \mathrm{C}$ for $15 \mathrm{~h}$, and then quenched in liquid nitrogen.

\subsection{Structural Characterization}

The chemical compositions were determined by inductively coupled plasma optical emission spectroscopy (ICP-OES, Varian 715 ES). Powder X-ray diffraction (XRD) analysis was carried out with a Rigaku Miniflex 600 in a $2 \theta$ range of 10 - 80 o with a scan speed of 10 per min with Cu Ka radiation. Lattice parameters and weight ratios of the two phases were further revealed by Rietveld refinement based on 
the General Structure Analysis Software (GSAS).[23] Particle morphology and energy dispersive X-ray (EDX) elemental mapping were characterized by scanning electron microscopy (SEM, FEI Quanta 650). Asprepared cathode powders were dusted on carbon grids for transmission electron microscopy (TEM). A probe Cs-corrector scanning/TEM microscope (FEI Titan ${ }^{\mathrm{TM}} 80-300$ operated at $300 \mathrm{kV}$ ) was used for high angle annular dark filed (HAADF) imaging and EDX analysis. Under the STEM mode, the electron beam had a convergence angle of 17.8 mrad and HAADF signal was collected by the annular detector in the range of 55-220 mrad. Another FEI Titan ${ }^{\mathrm{TM}}$ 80-300 microscope with image Cs-corrector was used for selective area electron diffraction (SAED) and high-resolution transmission electron microscopy (HRTEM).

\subsection{Electrochemical Measurements}

Electrochemical charge-discharge measurements were carried out with CR2032 coin cells. First, the cathode slurry was prepared by mixing the active material, carbon black (Super P), and polyvinylidene fluoride (PVDF, Kureha KF 1120) in N-methyl-2-pyrrolidone (NMP) solution with a weight ratio of, respectively, 80: 10: 10. Then, the slurry was homogeneously deposited onto an aluminum foil current collector. After drying it at $120^{\circ} \mathrm{C}$ under vacuum overnight, the typical loading of the electrode was $3.0-$ $4.0 \mathrm{mg} \mathrm{cm}^{-2}$. All coin cells were assembled in an Ar-filled glove-box with the as-prepared cathode, Li metal as an anode, one piece of polypropylene separator (Celgard 2500), and an electrolyte consisting of $1 \mathrm{M}$ $\mathrm{LiPF}_{6}$ in $1: 1$ ethylene carbonate (EC) and diethyl carbonate (DEC) mixture, unless otherwise specified in the text. An Arbin cycler was used to perform electrochemical charge/discharge tests, where $1 \mathrm{C}$ rate is

equal to $180 \mathrm{~mA} \mathrm{~g}^{-1}$. Electrochemical impedance spectroscopy (EIS) analysis was conducted with a Solartron $1260 \mathrm{~A}$ impedance analyzer. For each cycling stage, all the cells (cycled at C/2 rate in a voltage window of $3.0-4.5 \mathrm{~V}$ ) were charged to the same state of charge (SOC, $4.2 \mathrm{~V}$ ) and held for another $3 \mathrm{~h}$ before the EIS measurement. Differential capacity plots (DCP) of dQ/dV vs. voltage were calculated based on the charge/discharge data of the corresponding cycle.

\section{Results and Discussion}

Table 1 summarizes the ICP results of the $x \mathrm{Li}_{2} \mathrm{MnO}_{3} \cdot(1-x) \mathrm{LiNi}_{0.7} \mathrm{Co}_{0.15} \mathrm{Mn}_{0.15} \mathrm{O}_{2}(\mathrm{x}=0,0.03,0.07$, and 0.10$)$ samples. Comparing the calculated and experimentally observed chemical compositions, it is evident that 
the amounts of all transition-metal ions are almost equal to the designed values. Figure S1 shows the XRD patterns of the $x \mathrm{Li}_{2} \mathrm{MnO}_{3} \cdot(1-\mathrm{x}) \mathrm{LiNi}_{0.7} \mathrm{Co}_{0.15} \mathrm{Mn}_{0.15} \mathrm{O}_{2}(x=0,0.03,0.07,0.10,0.20$, and 0.30$)$ samples. All strong peaks could be easily indexed to a rhombohedral phase with 3 symmetry, which clearly indicates a highly crystallized layered structure regardless of the chemical composition. Interestingly, the enlarged XRD patterns in the $2 \theta$ range of $20-30^{\circ}, 44-45^{\circ}$, and $63-69^{\circ}$ imply a gradually increasing amount of $\mathrm{Li}_{2} \mathrm{MnO}_{3}$-phase formation with $\mathrm{C2} / \mathrm{m}$ symmetry with increasing $\mathrm{x}$ value. Typically, as one of the strongest evidences of $\mathrm{Li}_{2} \mathrm{MnO}_{3}$ phase, a hump located at around $21^{\circ}$ is a consequence of an ordering when $1 / 3$ of Li ions occupy the transition-metal layer leading to this superlattice peak apparent.[15] Meanwhile, shifting and broadening of the (104) peak toward the higher angle imply nucleation and growth of a new Li-rich layered phase which possesses very similar symmetry to the original phase. In order to investigate the evolution of lattice parameters and weight ratios, a two-phase Rietveld refinement was performed with GSAS and the results are shown in Table 2. It is necessary to point out that the two-phase refinement is hard when $x=0.03$ since the formation and signal from $\mathrm{Li}_{2} \mathrm{MnO}_{3}$ phase is too small to be detected. Regarding the lattice parameters $a$ and $c$ of the 3 phase, it is apparent that both of them jump when $x$ changes from 0.07 to 0.10 , indicating a recognizable formation of $C 2 / \mathrm{m}$ phase afterward. Before and after this separation point, the changes in both the $a$ and $c$ parameters of the 3 phase is relatively small, indicating less changes in the valence states of the transition-metal ions, occupancy of oxygen ions, etc. Another observation from the refinement is that the extent of $\mathrm{Li}^{+} / \mathrm{Ni}^{2+}$ cation mixing has barely changed with increasing amount of $\mathrm{Li}_{2} \mathrm{MnO}_{3}$ phase from 0 to 0.1 , implying a negligible effect of $\mathrm{Li}_{2} \mathrm{MnO}_{3}$-integration on the atomic ratio of $\mathrm{Ni}^{2+} / \mathrm{Ni}^{3+}$. However, the errors in the determination of the lattice parameters of the $C 2 / \mathrm{m}$ phase are relatively large due to the low content of this phase. Nevertheless, $R_{p}$ remains small throughout the series of refinement. Respective weight fractions of both 3 and $C 2 / m$ phases calculated based on the refinement are shown in Figure S2. Compared to the target amount of $\mathrm{Li}_{2} \mathrm{MnO}_{3}$, the realistic values are clearly lower possibly due to a weak ordering of $\mathrm{LiMn}_{6}$ in local lattice as a result of the co-existence of $\mathrm{Ni}$ and Co. It is also important to note that calculation of the weight fraction from a two-phase refinement is normally carried out for composite 


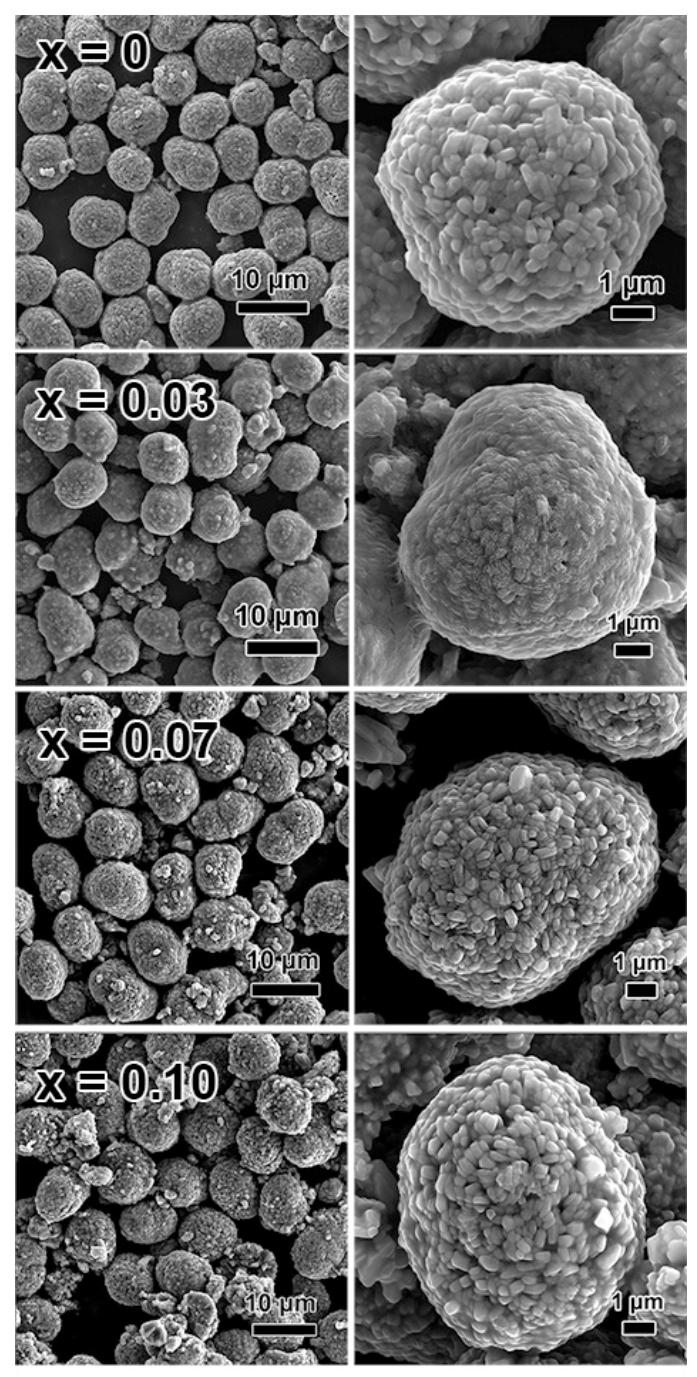

Fig. 1 SEM images of the $x \mathrm{Li}_{2} \mathrm{MnO}_{3} \cdot(1-\mathrm{x}) \mathrm{LiNi}_{0.7} \mathrm{Co}_{0.15} \mathrm{Mn}_{0.15} \mathrm{O}_{2}(x=0,0.03,0.07$, and 0.10) powders.

materials, while in the case of Li-rich layered oxides, only a nano-domain composite structure has been reported, where whether composite structure exists is still debatable.[24, 25] This is another possible reason for the discrepancy between the observed and designed values.

Figure 1 shows the particle morphology of the $x \mathrm{Li}_{2} \mathrm{MnO}_{3} \cdot(1-\mathrm{x}) \mathrm{LiNi}_{0.7} \mathrm{Co}_{0.15} \mathrm{Mn}_{0.15} \mathrm{O}_{2}(x=0,0.03,0.07$, and 0.10) samples. As can be seen, all samples have a spherical or elliptical shape and a uniformly distributed particle size of around $9 \mu \mathrm{m}$ in diameter, which are important to achieve high tap density and thus high volumetric energy density. The overall morphology of the secondary particles has barely changed after the modification with $\mathrm{Li}_{2} \mathrm{MnO}_{3}$ as the $\mathrm{x}$ value increases, except that a certain amount of small particles are 

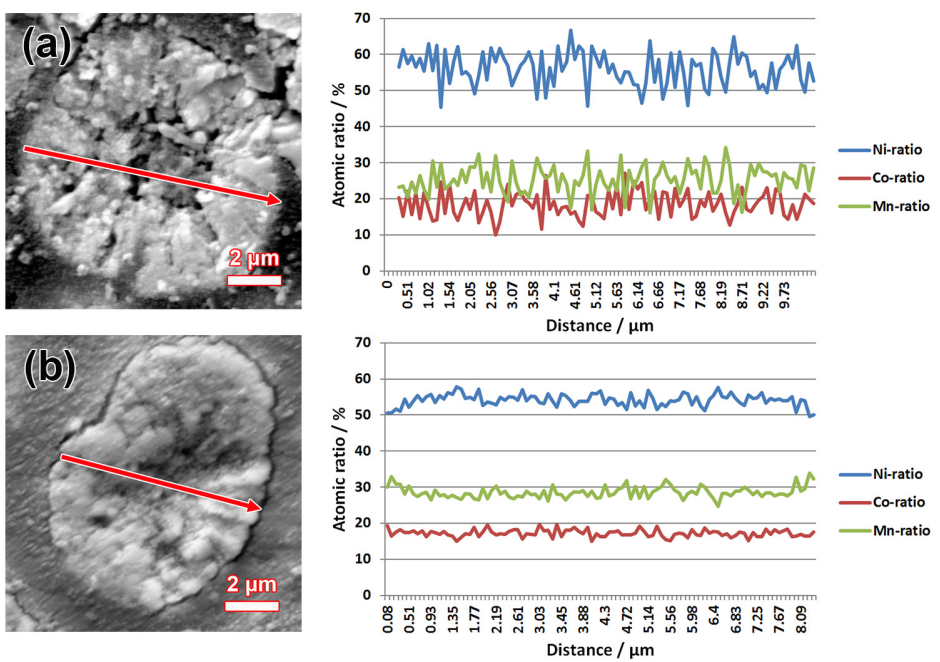

Fig. 2 SEM-EDX line scan of $\mathrm{Ni}, \mathrm{Co}$, and $\mathrm{Mn}$ at cross section of $\mathrm{xLi}_{2} \mathrm{MnO}_{3} \cdot(1-\mathrm{x}) \mathrm{LiNi}_{0.7} \mathrm{CO}_{0.15} \mathrm{Mn}_{0.15} \mathrm{O}_{2}$ particles: (a) $x=0$ and (b) $x=0.10$.

present with less than $500 \mathrm{~nm}$ in size due to the addition of $\mathrm{MnCO}_{3}$ as raw material during synthesis. It is easy to understand that decomposition of $\mathrm{MnCO}_{3}$ leads to $\mathrm{MnO} / \mathrm{Mn}_{3} \mathrm{O}_{4} / \mathrm{MnO}_{2}$ formation at high temperatures, which hardly melts during the employed heating process. Images with higher magnification in Figure 1 also show the size distribution and shape of the primary particles. It could be seen that the primary particles are around $300 \mathrm{~nm}$ in size, which barely changes with increasing $x$ from 0 to 0.1 .

To investigate the distribution extent of $\mathrm{Mn}$ along the radial direction of one secondary particle, linescan SEM-EDX on cross-sections of secondary particle was carried out for both the $\mathrm{LiNi}_{0.7} \mathrm{Co}_{0.15} \mathrm{Mn}_{0.15} \mathrm{O}_{2}$ and $0.1 \mathrm{Li}_{2} \mathrm{MnO}_{3} \cdot 0.9 \mathrm{LiNi}_{0.7} \mathrm{Co}_{0.15} \mathrm{Mn}_{0.15} \mathrm{O}_{2}$ samples, and the results are shown in Figure 2 . As can be seen for the pristine particle, the atomic ratios of $\mathrm{Ni}, \mathrm{Co}$, and $\mathrm{Mn}$ typically fluctuate, respectively, at around 55, 20 , and $25 \%$ throughout the cross section, indicating a long-range homogeneous distribution of all transitionmetal ions. Note that the relative increase in both $\mathrm{Co}$ and $\mathrm{Mn}$ at the expense of $\mathrm{Ni}$ originates from instrumental error as ICP results in Table 1 have already confirmed the chemical composition of the samples in a large scale. In comparison, in the case of the $0.1 \mathrm{Li}_{2} \mathrm{MnO}_{3} \cdot 0.9 \mathrm{LiNi}_{0.7} \mathrm{Co}_{0.15} \mathrm{Mn}_{0.15} \mathrm{O}_{2}$ particle, although the atomic ratios of all three ions again exhibit homogeneous distribution in the bulk, it is apparent that at the particle surface $\mathrm{Mn}$ increases to $30 \%$ when $\mathrm{Ni}$ and Co decrease to 53 and $17 \%$. 
Figures S3 and S4 in the supporting information show the cross section SEM-EDX elemental mappings of the pristine $\mathrm{LiNi}_{0.7} \mathrm{Co}_{0.15} \mathrm{Mn}_{0.15} \mathrm{O}_{2}$ and modified $0.1 \mathrm{Li}_{2} \mathrm{MnO}_{3} \cdot 0.9 \mathrm{LiNi}_{0.7} \mathrm{Co}_{0.15} \mathrm{Mn}_{0.15} \mathrm{O}_{2}$ samples, and further confirm the uniform distribution of the three transition-metal ions without any evidence of core-shell structure. According to the above observations, it is reasonable to conclude that $\mathrm{Mn}$ is able to diffuse from surface to bulk regions and being crystallized into local lattice even though the diffusion path is up to several micrometers. The high-temperature firing at $800{ }^{\circ} \mathrm{C}$ provides enough ionic mobility for diffusion. However, it is also important to note that although Mn shows a long-range homogeneous distribution, it is still possible that $\mathrm{Mn}$ could be locally enriched to form Li- and Mn-rich phases within a region of several nanometers given the EDX resolution. In fact, STEM results in a later section will provide direct evidence of a two-phase coexistence at the local region of one particle.

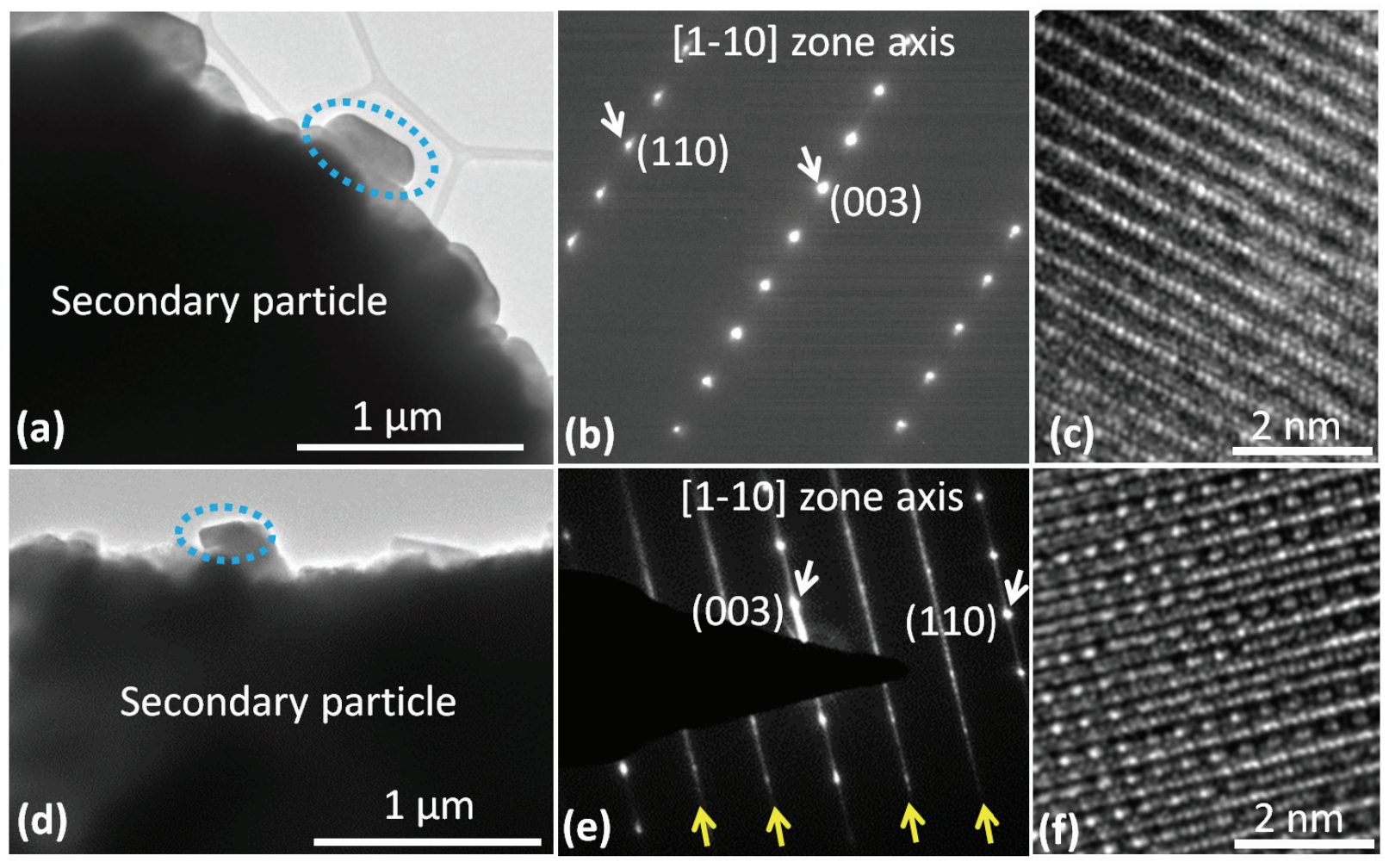

Fig. 3 Conventional TEM characterization of the $(a-c) x=0$ sample and ( $d-f)$ the $x=0.1$ sample; (a) and (d) are lowmagnification bright field TEM images, and (b) and (e) are corresponding SAED patterns of the surface particles in (a) and (d), respectively; (c) and ( $f$ ) are corresponding HRTEM images. 
Figures $3 a, 3 b$, and 3c present the conventional TEM images of the pristine $(x=0)$ sample. Selected area electron diffraction (SAED) image from the highlighted area of Figure $3 a$ is shown in Figure $3 b$, where it could be easily indexed with the 110 rhombohedral zone axis. In addition, the HRTEM image shown in Figure $3 c$ exhibits a typical layered structure with 3 symmetry. In comparison, Figures $3 d, 3 e$, and $3 f$ present TEM images of the modified $(x=0.10)$ sample. As shown by the SAED in Figure 3e, besides indexing with a typical layered structure with 3 symmetry, there is an additional set of streaks that is due to the formation of monoclinic structure domains with $C 2 / m$ symmetry, which is highlighted by a series of yellow arrows.[26] Again, the HRTEM image in Figure 3f from a small domain selected from the highlighted area of Figure $3 d$ confirms a $C 2 / m$-phase lattice.

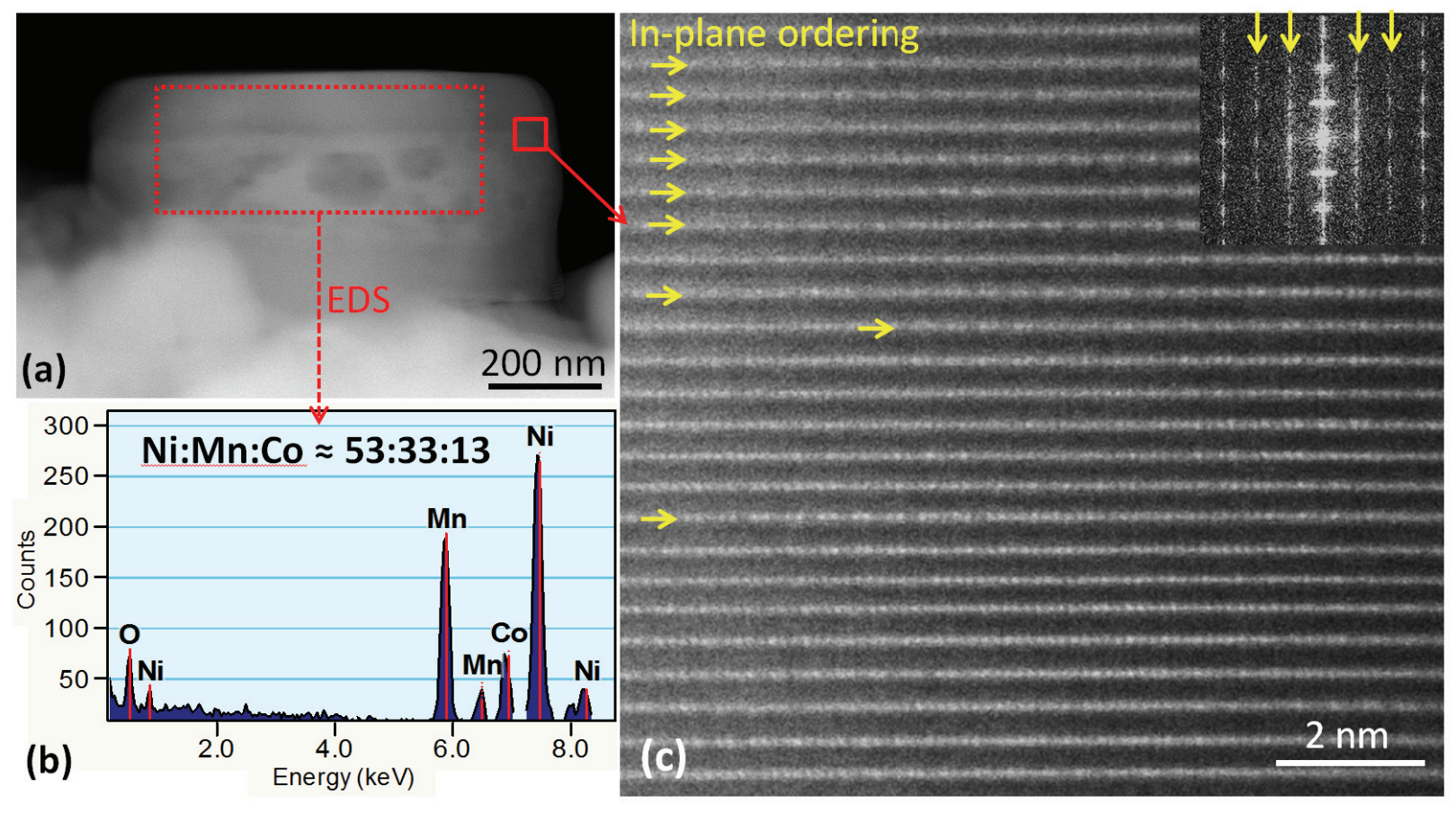

Fig. 4 (a) Low-magnification STEM-HAADF image of one surface primary particle of the $x=0.10$ sample. (b) Corresponding X-ray spectrum from the highlighted area in (a). (c) High-resolution STEM-HAADF image showing the lattice structure from the highlighted area in (a). The inset in (c) shows the corresponding FFT image.

To provide more information on the modified particle, STEM-HAADF imaging was conducted. As shown in Figure 4a, a surface primary particle was investigated. Figure 4c shows a high-resolution HAADF-STEM 
image with identifiable lattice construction from the highlighted area of Figure $4 a$. Clearly, a $C 2 / m$ symmetry featured transition-metal in-plane ordering is verified and highlighted by yellow arrows, while the rest shows the 3 symmetry. The inset of Figure $4 \mathrm{c}$ is the corresponding Fast Fourier Transform (FFT) image, in which the extra diffraction spots highlighted by yellow arrows also confirmed the existence of $\mathrm{C} 2 / \mathrm{m}$ phase. Furthermore, it is interesting to point out that the EDX atomic ratio of $\mathrm{Ni}: \mathrm{Mn}:$ Co from the selected area of the primary particle (Figure $4 a$ ) is $53: 33: 13$. It agrees well with the SEM-EDX result of the cross section of a whole secondary particle. This implies that (i) this modification method induces a relatively uniform integration of additional $\mathrm{Mn}$ into the local lattice throughout the whole secondary particles, and (ii) an ordering of the Li-rich phase with $C 2 / m$ symmetry, prompted by the enrichment of $\mathrm{Mn}$, only occurs in a small domain island within several nanometers, which is surrounded by the pristine layered phase with 3 symmetry. However, note that normally the Li-rich phase has been observed only when $\mathrm{Mn}$ is above 0.5 in $\mathrm{Li}_{1+\delta} \mathrm{Ni}_{x} \mathrm{Mn}_{y} \mathrm{M}_{1-x-y-\delta} \mathrm{O}_{2} \cdot[15,16,27]$ Thus, a local separation in terms of phase and chemical composition (Ni-enriched and $\mathrm{Mn}$-enriched) within a region of several nanometers probably occurs, giving rise to the overall atomic ratio of $\mathrm{Ni}: \mathrm{Mn}: \mathrm{Co}=53: 33: 13$. This is the first time to directly observe the formation of a Li-rich $\mathrm{C} 2 / \mathrm{m}$ phase within a Ni-rich layered particle at the nano-scale. It demonstrates that it is possible to form Li-rich $\mathrm{C2} / \mathrm{m}$ phase in a Ni-rich layered oxide by applying an proper chemical-compositional design and heating method.

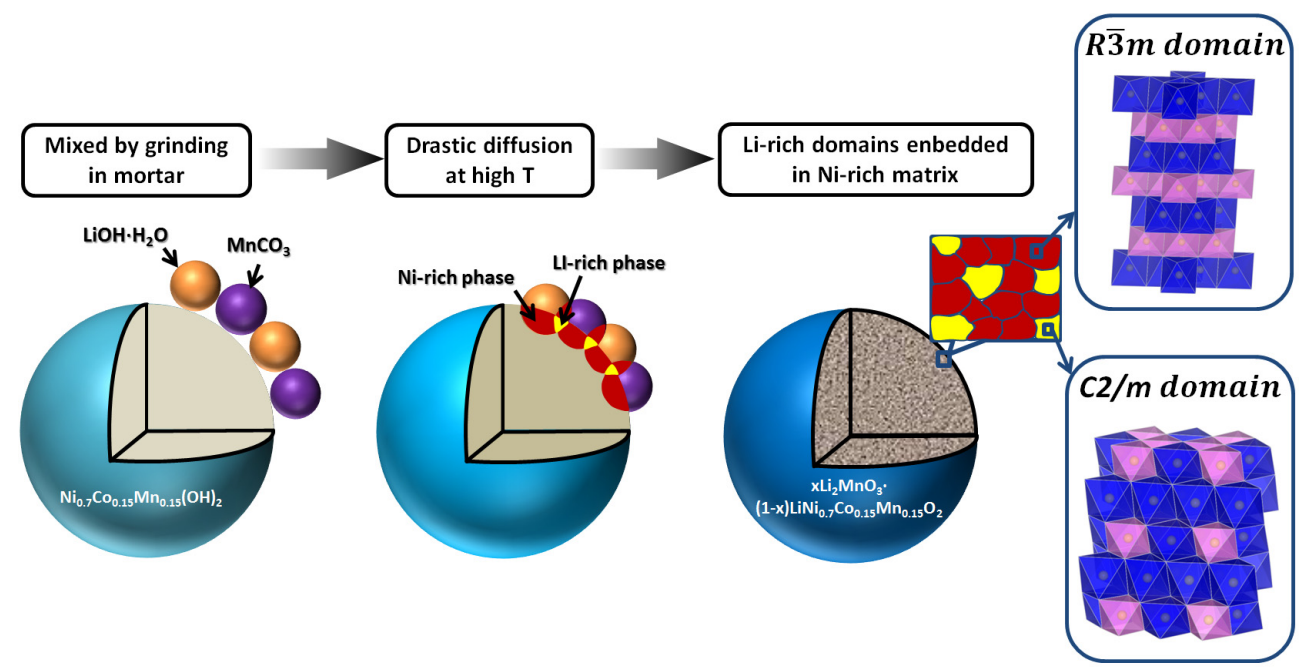

Fig. 5 Schematic illustration of the synthesis strategy and the consequent effects on structural change. 

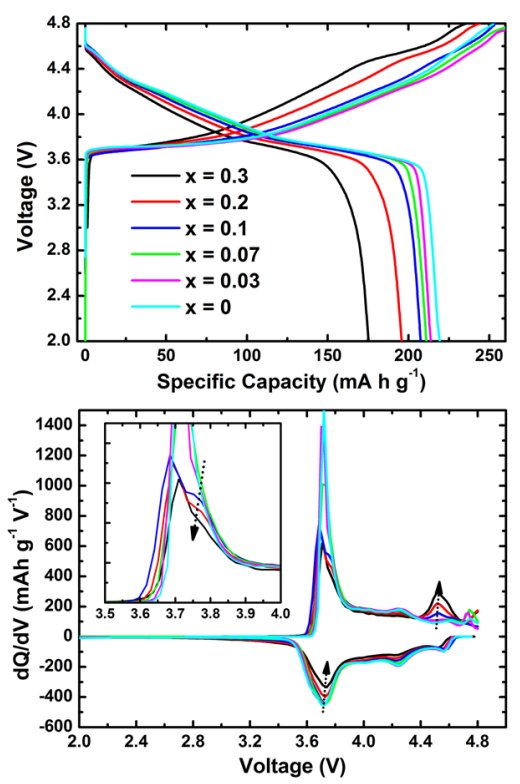

Fig. 6 Charge-discharge curves and corresponding dQ/dV plots of the $\mathrm{xLi}_{2} \mathrm{MnO}_{3} \cdot(1-\mathrm{x}) \mathrm{LiNi}_{0.7} \mathrm{Co}_{0.15} \mathrm{Mn}_{0.15} \mathrm{O}_{2}(\mathrm{x}$ $=0,0.03,0.07,0.10,0.20$, and 0.30 ) cathodes cycled in a voltage window of $2.0-4.8 \mathrm{~V}$ at $\mathrm{C} / 20$ rate.

Based on these observations from XRD, SEM-EDX, and STEM, Figure 5 summarizes the synthesis strategy and consequent structural changes for the $\mathrm{xLi}_{2} \mathrm{MnO}_{3} \cdot(1-\mathrm{x}) \mathrm{LiNi}{ }_{0.7} \mathrm{Co}_{0.15} \mathrm{Mn}_{0.15} \mathrm{O}_{2}$ cathode materials. Hightemperature heating of a mixture of $\mathrm{Ni}_{0.7} \mathrm{Co}_{0.15} \mathrm{Mn}_{0.15}(\mathrm{OH})_{2}$ precursor, $\mathrm{MnCO}_{3}$, and $\mathrm{LiOH} \cdot \mathrm{H}_{2} \mathrm{O}$ at $800{ }^{\circ} \mathrm{C}$ for $15 \mathrm{~h}$ leads to a drastic diffusion of $\mathrm{Li}$ and $\mathrm{Mn}$ into the bulk particles of $\mathrm{Ni}_{0.7} \mathrm{Co}_{0.15} \mathrm{Mn}_{0.15}(\mathrm{OH})_{2}$. During the heating process, they crystallize into two types of thermodynamically-stable phases, 3 and $C 2 / m$ phases, governed by the local composition. Therefore, we speculate that some regions with enriched Mn generate $\mathrm{Li}$ - and $\mathrm{Mn}$ - rich phases, while the other regions with low concentration of $\mathrm{Mn}$ only form the $\mathrm{Ni}$ rich phase. Furthermore, $\mathrm{Li}$ - and $\mathrm{Mn}$ - rich phases $(\mathrm{C} 2 / \mathrm{m})$ exist in the form of nano-domain islands, surrounded by the bulk Ni-rich phase ( 3 ). These nano-domain islands are too small for SEM-EDX to be identified in terms of the local variation of $\mathrm{Mn}$ between these two phases. According to two studies conducted by Sun's group [22] and Dahn's group [9], Li-rich phase has been observed in $\mathrm{Li}_{1.033} \mathrm{Ni}_{0.855} \mathrm{Co}_{0.045} \mathrm{Mn}_{0.067} \mathrm{O}_{2}$ and in a core-shell structure with the chemical formula $0.67 \mathrm{Li}_{1.06}\left(\mathrm{Ni}_{0.67} \mathrm{Mn}_{0.33}\right)_{0.94} \mathrm{O}_{2} \cdot 0.33 \mathrm{Li}_{1.2}\left(\mathrm{Ni}_{0.2} \mathrm{Mn}_{0.6} \mathrm{Co}_{0.2}\right)_{0.8} \mathrm{O}_{2}$, which is also termed as $\mathrm{Li}_{1.106} \mathrm{Ni}_{0.473} \mathrm{Mn}_{0.368} \mathrm{Co}_{0.053} \mathrm{O}_{2}$. In both cases, additional $\mathrm{Li}^{+}$ions at the transition-metal sites were purposely 
designed and $\mathrm{Mn}$ has an oxidation state higher than 3+. Similarly, in our case, taking $0.1 \mathrm{Li}_{2} \mathrm{MnO}_{3} \cdot 0.9 \mathrm{LiNi}_{0.7} \mathrm{Co}_{0.15} \mathrm{Mn}_{0.15} \mathrm{O}_{2}$ as an example, a chemical composition of $\mathrm{Li}_{1.064} \mathrm{Ni}_{0.589} \mathrm{Co}_{0.126} \mathrm{Mn}_{0.221} \mathrm{O}_{2}$ was confirmed by ICP, where two conditions, i.e., some $\mathrm{Li}^{+}$ions at the transition-metal sites and an average valence state of $>3+$ for $\mathrm{Mn}$ are satisfied. However, inter-diffusion among $\mathrm{Ni}, \mathrm{Co}$, and $\mathrm{Mn}$ can occur during high-temperature sintering $\left(>700^{\circ} \mathrm{C}\right)$. Dahn et al. [28] has shown that the inter-diffusion coefficient of $\mathrm{Ni}^{3+} / \mathrm{Mn}^{4+}$ couple is an order of magnitude lower than that of $\mathrm{Ni}^{3+} / \mathrm{Co}^{3+}$. This result suggests the possibility of forming a Mn-enriched region in the local structure, especially when excess Li is present. Based on the above considerations, we presume that if the chemical composition of Ni-rich oxide is carefully designed with two conditions (additional $\mathrm{Li}^{+}$ions at the transition-metal sites and partial $\mathrm{Mn}^{4+}$ formation to maintain charge neutrality), Li-rich phase could be formed in the presence of Ni-rich phase. As a consequence, the direct oxidation reaction between $\mathrm{Ni}^{4+}$ and electrolyte and thus the growth of solidelectrolyte interfacial (SEI) layer is suppressed due to the existence and the shielding effects from the Lirich nano-domains at the surface region of the secondary particle. Meanwhile, the existence of Li-rich nano-domains also likely function as a pinning point to prohibit the phase transition in Ni-rich particles, which normally starts from the particle surface. These effects could benefit in enhancing the cyclability. In fact, the electrochemical cycling in a later section will show clear evidences of such enhancements.

Figure 6 shows the initial charge-discharge profiles of the $x \mathrm{Li}_{2} \mathrm{MnO}_{3} \cdot(1-x) \mathrm{LiNi}_{0.7} \mathrm{Co}_{0.15} \mathrm{Mn}_{0.15} \mathrm{O}_{2}(x=0,0.03$, $0.07,0.10,0.20$, and 0.30 ) cathodes cycled in a voltage window of $2.0-4.8 \mathrm{~V}$ at $\mathrm{C} / 20$ rate. The upper charge cut-off voltage of $4.8 \mathrm{~V}$ was chosen to fully activate the $\mathrm{Li}_{2} \mathrm{MnO}_{3}$-like component in all samples to understand its effects on the reversible capacity.[29] As shown in Figure 6, in this voltage range, the discharge capacities are 220, 214, 211, 208, 196, and $175 \mathrm{~mA} \mathrm{~h} \mathrm{~g}{ }^{-1}$ with coulombic efficiencies of 87.3 , $81.1,79.9,81.1,80.3$, and $74.2 \%$, respectively, for the $x=0,0.03,0.07,0.10,0.20$, and 0.30 samples. It is clear that the discharge capacity gradually decreases with increasing $x$, even though the coulombic efficiency varies. This observation on the reduction of reversible capacity when integrating higher amount of $\mathrm{Mn}^{4+}$ from $\mathrm{Li}_{2} \mathrm{MnO}_{3}$ component is consistent with the results reported in the literature. ${ }^{22}$ It could be ascribed to the reduced amount of $\mathrm{Ni}^{3+} / \mathrm{Ni}^{4+}$ redox. Plots of $\mathrm{dQ} / \mathrm{dV}$ in Figure 6 indicate the evolutions of different redox peaks. Specifically, the intensity of the $\mathrm{Ni}^{3+} / \mathrm{Ni}^{4+}$ redox peak located at around $3.75 \mathrm{~V}$ 
decreases with increasing $\mathrm{x}$ value. Besides, this redox peak also shifts slightly, implying a reduced polarization effect in the presence of $\mathrm{Mn}^{4+} \cdot[30]$

In contrast, increasing intensity of the charging peak at $4.5 \mathrm{~V}$ with higher $\mathrm{x}$ values apparently indicates the formation of $\mathrm{Li}_{2} \mathrm{MnO}_{3}$-like component, which agrees well with the XRD and TEM results. Johnson et al. reported a series of $x \mathrm{Li}_{2} \mathrm{MnO}_{3} \cdot(1-\mathrm{x}) \mathrm{LiNi}_{1 / 3} \mathrm{Co}_{1 / 3} \mathrm{Mn}_{1 / 3} \mathrm{O}_{2}$ cathode materials in the literature.[31] They found that the $0.1 \mathrm{Li}_{2} \mathrm{MnO}_{3} \cdot 0.9 \mathrm{LiNi}_{1 / 3} \mathrm{Co}_{1 / 3} \mathrm{Mn}_{1 / 3} \mathrm{O}_{2}$ cathode delivers a discharge capacity lower than the pristine $\mathrm{LiNi}_{1 / 3} \mathrm{Co}_{1 / 3} \mathrm{Mn}_{1 / 3} \mathrm{O}_{2}$ when charging to $4.6 \mathrm{~V}$, while increasing $\mathrm{x}$ to $0.3,0.5$, and 0.7 leads to much higher discharge capacities than the pristine one at the same charge-discharge condition. This observation implies that the overall molar ratio of $\mathrm{Mn}$ relative to $\mathrm{Ni}$ or Co must reach a critical point so that the additional reversible capacity at the lower part of $3.5 \mathrm{~V}$ could be triggered; otherwise, the overall reversible capacity decreases due to a loss of $\mathrm{Ni}^{2+} / \mathrm{Ni}^{4+}$ redox. Similarly, since the highest $\mathrm{Mn}$-content composition in our case is $\mathrm{Li}_{1.13} \mathrm{Ni}_{0.46} \mathrm{Co}_{0.09} \mathrm{Mn}_{0.35} \mathrm{O}_{2}(x=0.3)$, where $\mathrm{Mn}$ content is still lower than $\mathrm{Ni}$, this material is a Ni-rich overall rather than Mn-rich layered oxide in terms of chemical composition. Therefore, it is understandable that the value of the initial discharge capacity decreases with increasing $\mathrm{x}$ from 0 to 0.3 as shown in Figure 6 . We speculate that although both $\mathrm{Li}^{+}$and $\mathrm{O}^{2-}$ ions could be extracted from the local $\mathrm{C} 2 / \mathrm{m}$ domains, the non-activity of $\mathrm{O}^{2-} / \mathrm{O}^{-}$and/or $\mathrm{Mn}^{4+} / \mathrm{Mn}^{3+}$ redox reactions is responsible for the reduced reversible capacity in our case, but it commonly contributes to the capacity in other "real" Li- Mn-rich layered oxides.[32-34] This is supported by an absent peak that is normally observed at the lower part of $3.5 \mathrm{~V}$ in Figure 6. Such an observation of reduced capacity in Ni-rich layered oxides in the presence of a Li-rich phase also implies a competing relationship between $\mathrm{Ni}$ and $\mathrm{Mn}$ in determining the active redox mechanisms. In this regard, we only focused on the electrochemical performance of $\mathrm{xLi}_{2} \mathrm{MnO}_{3} \cdot(1-\mathrm{x}) \mathrm{LiNi}_{0.7} \mathrm{CO}_{0.15} \mathrm{Mn}_{0.15} \mathrm{O}_{2}$ oxides when $\mathrm{x}$ is smaller than 0.1 in order to strike a balance between the reduced capacity and the enhanced stability. 

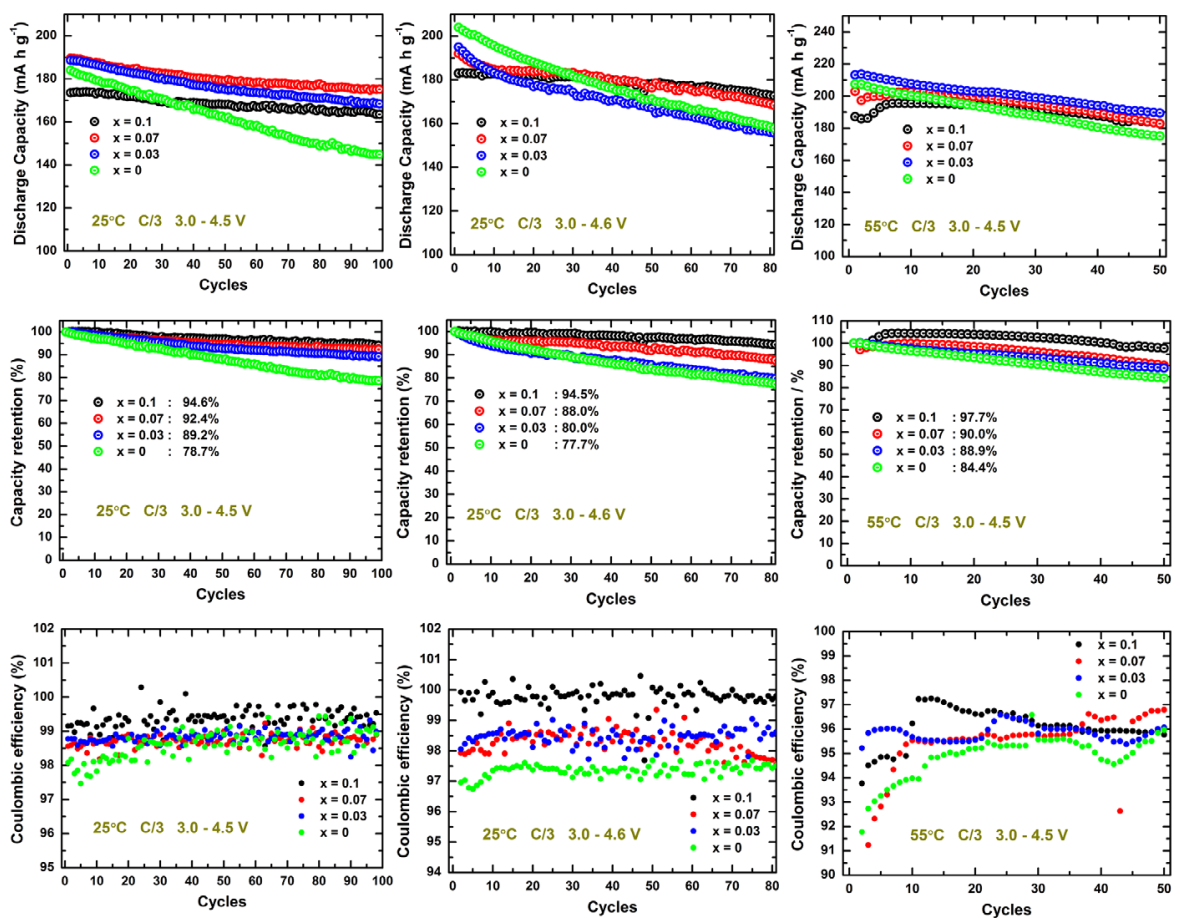

Fig. 7 Cycle performance of the $\mathrm{xLi}_{2} \mathrm{MnO}_{3} \cdot(1-\mathrm{x}) \mathrm{LiNi} \mathrm{in}_{0.7} \mathrm{Co}_{0.15} \mathrm{Mn}_{0.15} \mathrm{O}_{2}(x=0,0.03,0.07$, and 0.10$)$ cathodes tested

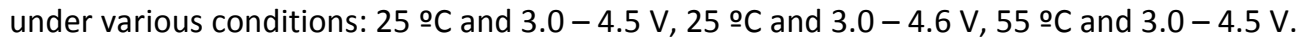

The cycle performances at $\mathrm{C} / 3$ rate of the $\mathrm{xLi}_{2} \mathrm{MnO}_{3} \cdot(1-\mathrm{x}) \mathrm{LiNi}_{0.7} \mathrm{Co}_{0.15} \mathrm{Mn}_{0.15} \mathrm{O}_{2}(\mathrm{x}=0,0.03,0.07$, and 0.10$)$ cathodes under various conditions are shown in Figure 7, i.e., at $25{ }^{\circ} \mathrm{C}$ and $3.0-4.5 \mathrm{~V}, 25{ }^{\circ} \mathrm{C}$ and $3.0-4.6$ $\mathrm{V}, 55{ }^{\circ} \mathrm{C}$ and $3.0-4.5 \mathrm{~V}$. With the condition of $25^{\circ} \mathrm{C}$ and $3.0-4.5 \mathrm{~V}$, the initial discharge capacity is 185 , 188,189 , and $173 \mathrm{~mA} \mathrm{~h} \mathrm{~g}^{-1}$, respectively, for the $\mathrm{x}=0,0.03,0.07$, and 0.10 samples. It demonstrates that the reversible capacity is not affected notably when the integrated amount of $\mathrm{Li}_{2} \mathrm{MnO}_{3}$ is smaller than 7 mol\%. Additionally, the capacity retention over 100 cycles is improved from $78.7 \%$ for the pristine sample to $89.2,92.4$, and $94.6 \%$, respectively, for the $x=0.03,0.07$, and 0.10 samples, demonstrating that higher amount of $\mathrm{Li}_{2} \mathrm{MnO}_{3}$ results in better cyclability. As increasing the charge cut-off voltage from 4.5 to $4.6 \mathrm{~V}$, the initial discharge capacity increases to $204,195,192$, and $183 \mathrm{~mA} \mathrm{~h} \mathrm{~g}^{-1}$, respectively, for the $\mathrm{x}=0,0.03$, 0.07 , and 0.10 samples. Again, the capacity retention after 80 cycles is improved from $77.7 \%$ for the pristine sample to 80,88 , and $94.5 \%$, respectively, for the $x=0.03,0.07$, and 0.10 . Under this cycling condition, it is clear that the coulombic efficiency throughout all cycles of the modified samples is higher 
than the pristine counterpart. It suggests the enhanced surface stability for the modified samples with suppressed surface side reactions with electrolyte especially when the voltage is higher than $4.5 \mathrm{~V}$. Furthermore, the extent of surface stability is a function of $\mathrm{Li}_{2} \mathrm{MnO}_{3}$ content. As well-known, the poor cycle performance of the Ni-rich layered cathodes at elevated temperatures is its most considerable drawback. In our case, the capacity retention over 50 cycles is improved from $84.4 \%$ for pristine sample to $88.9,90$, and $97.7 \%$, respectively, for the $x=0.03,0.07$, and 0.10 samples. It will be shown later that the cycling test at $55 \stackrel{\circ}{\circ}$ with a modified electrolyte could provide even better cyclability. All the results in terms of initial discharge capacity, capacity retention, and average coulombic efficiency are summarized in Table 3. Figure S5 in the supporting information shows the electrochemical performance of the $0.1 \mathrm{MnO}_{2} \cdot 0.9 \mathrm{LiNi}_{0.7} \mathrm{Co}_{0.15} \mathrm{Mn}_{0.15} \mathrm{O}_{2}$ cathode. Notably, both the initial capacity and cyclability are not comparable to that of the $0.1 \mathrm{Li}_{2} \mathrm{MnO}_{3} \cdot 0.9 \mathrm{LiNi}_{0.7} \mathrm{Co}_{0.15} \mathrm{Mn}_{0.15} \mathrm{O}_{2}$ cathode. The results indicate the advantage of $\mathrm{Li}_{2} \mathrm{MnO}_{3}$-like component formation.

The charge-discharge curves and the corresponding $\mathrm{dQ} / \mathrm{dV}$ plots with the cycle number of the $\mathrm{LiNi}_{0.7} \mathrm{Co}_{0.15} \mathrm{Mn}_{0.15} \mathrm{O}_{2}$ and $0.07 \mathrm{Li}_{2} \mathrm{MnO}_{3} \cdot 0.93 \mathrm{LiNi}_{0.7} \mathrm{Co}_{0.15} \mathrm{Mn}_{0.15} \mathrm{O}_{2}$ cathodes at 55 o $\mathrm{C}$ are shown in Figure S6. It is apparent that the polarization effects in terms of voltage increase upon charge and voltage drop upon discharge are both significantly reduced during 50 cycles because of the $\mathrm{Li}_{2} \mathrm{MnO}_{3}$ modification, as indicated by the arrows in Figure $\mathrm{S} 6 \mathrm{~b}$ and $\mathrm{S} 6 \mathrm{~d}$. Figure $\mathrm{S7}$ shows the rate capability of the $\mathrm{xLi}_{2} \mathrm{MnO}_{3} \cdot(1-$ $\mathrm{x}) \mathrm{LiNi}_{0.7} \mathrm{CO}_{0.15} \mathrm{Mn}_{0.15} \mathrm{O}_{2}(\mathrm{x}=0,0.03,0.07$, and 0.10$)$ samples. All the samples before and after modification exhibit good rate capability, ca. $62 \%$ of capacity retention at $10 \mathrm{C}$ compared to the discharge capacity obtained at C/10 rate. Specifically, the rate capability is slightly improved as the $x$ value increases from 0 to 0.10 . This is possibly due to the suppressed side reactions between particles' surface and electrolyte. It consequently leads to the formation of less inert species having poor $\mathrm{Li}^{+}$ion and electronic conductivity. Although the rate capability of Li-rich $x \mathrm{Li}_{2} \mathrm{MnO}_{3} \cdot(1-x) \mathrm{LiMO}_{2}$ oxides is always considered to be poor due to the presence of the $\mathrm{Li}_{2} \mathrm{MnO}_{3}$ phase, here in our case, the amount of $\mathrm{Li}_{2} \mathrm{MnO}_{3}$ is relatively small. In essence, we presume that the transport of both $\mathrm{Li}^{+}$ions and electrons is dominantly controlled by the surface species rather than bulk structure. 
Long-term cycling performances of the pristine $\mathrm{LiNi}_{0.7} \mathrm{Co}_{0.15} \mathrm{Mn}_{0.15} \mathrm{O}_{2}$ and modified $0.07 \mathrm{Li}_{2} \mathrm{MnO}_{3} \cdot 0.93 \mathrm{LiNi}_{0.7} \mathrm{Co}_{0.15} \mathrm{Mn}_{0.15} \mathrm{O}_{2}$ cathodes at 25 and 55 으 are shown in Figure $8 \mathrm{a}$ and $8 \mathrm{~b}$. Remarkably, 90.3 and $81.3 \%$ of capacity retention, respectively, after 400 and 200 cycles cycled at C/3 rate have been achieved, taking advantage of both the stabilized structure and the modified electrolyte. Additionally, Figure 8c shows $73.5 \%$ capacity retention after 900 cycles with laminated pouch full cell fabricated with $0.07 \mathrm{Li}_{2} \mathrm{MnO}_{3} \cdot 0.93 \mathrm{LiNi}_{0.7} \mathrm{Co}_{0.15} \mathrm{Mn}_{0.15} \mathrm{O}_{2}$ cathode and graphite anode.
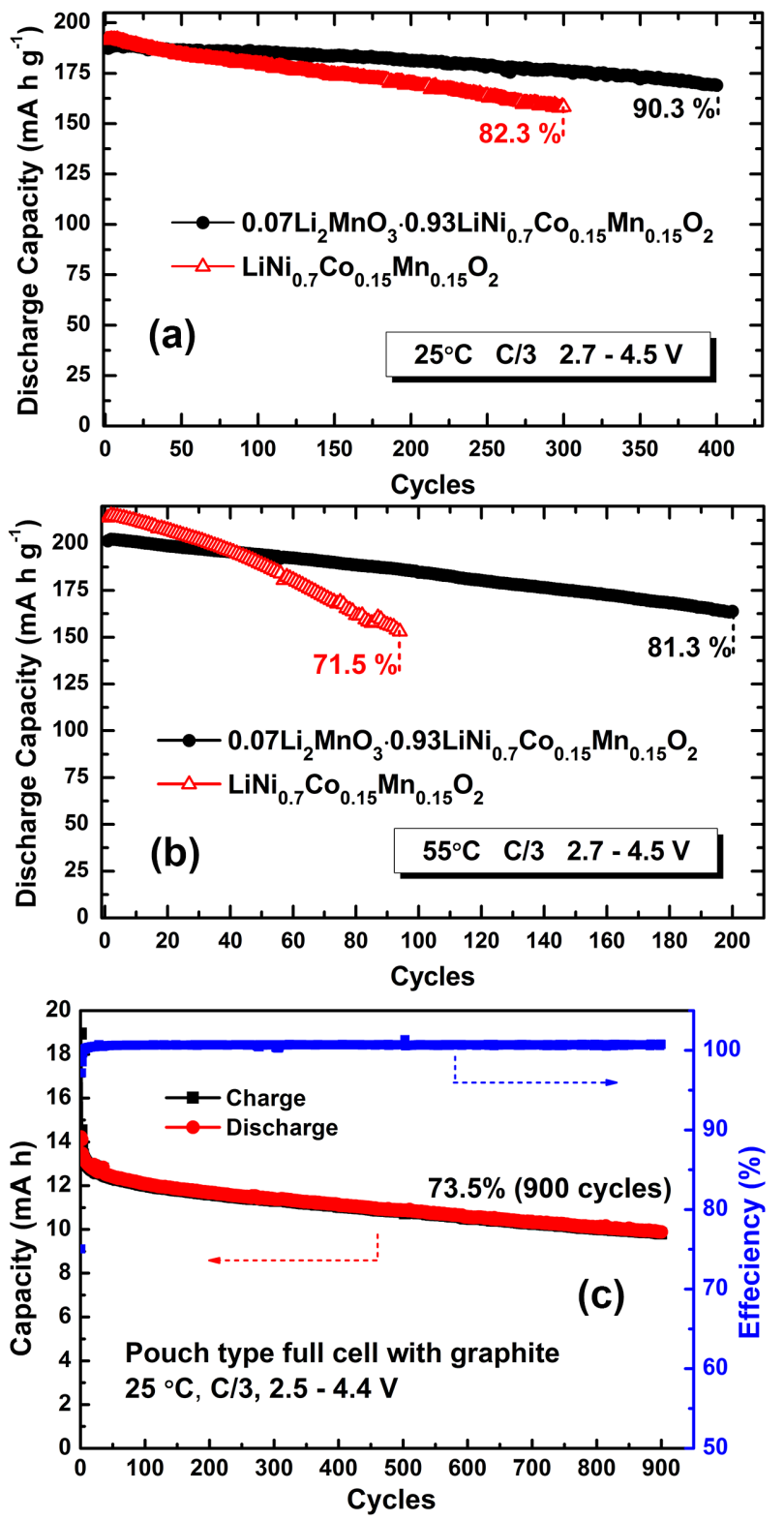
Fig. 8 Cycling performances of the pristine $\mathrm{LiNi}_{0.7} \mathrm{Co}_{0.15} \mathrm{Mn}_{0.15} \mathrm{O}_{2}$ and modified $0.07 \mathrm{Li}_{2} \mathrm{MnO}_{3} \cdot 0.93 \mathrm{LiNi}_{0.7} \mathrm{Co}_{0.15} \mathrm{Mn}_{0.15} \mathrm{O}_{2}$ cathodes in 1.2 $\mathrm{M} \mathrm{LiPF}_{6}$ in a $3: 7$ mixture of ethylene carbonate (EC) and ethylmethyl carbonate (EMC) electrolyte at (a) $25^{\circ} \mathrm{C}(\mathrm{a})$ and (b) at $55 \stackrel{\circ}{\circ} \mathrm{C}$, and (c) laminated-type pouch cell with the $0.07 \mathrm{Li}_{2} \mathrm{MnO}_{3} \cdot 0.93 \mathrm{LiNi}_{0.7} \mathrm{Co}_{0.15} \mathrm{Mn}_{0.15} \mathrm{O}_{2}$ cathode and graphite as anode. The pouch-type full cell was cycled at C/10 rate for first 2 cycles and at C/3 rate for the rest of the cycles.

AC impedance measurements were conducted to monitor the evolution of cell impedance with the pristine and modified cathode materials as a function of cycle number, i.e., $1^{\text {st }}, 10^{\text {th }}, 50^{\text {th }}$, and $100^{\text {th }}$ cycles. The Nyquist plots are shown in Figure S8. The first semicircle at high frequency is correlated with the resistance of $\mathrm{Li}^{+}$-ion migration through the solid-electrolyte interfacial layer $\left(\mathrm{R}_{\mathrm{s}}\right)$, while the second semicircle at middle-range frequency is associated with the charge-transfer resistance $\left(R_{c t}\right)$ between the surface film and the bulk cathode.[35] As can be seen, the $R_{c t}$ is significantly reduced with increasing integrated amount of $\mathrm{Li}_{2} \mathrm{MnO}_{3}$ from 0 to $0.03,0.07$, and 0.1 . Most importantly, this tendency of reduced $R_{c t}$ is quite consistent with each other from the initial cycle to the very end of $100^{\text {th }}$ cycle. This conclusion is supported by the fitting results of the Nyquist plots with an equivalent circuit, and the values are shown in Table 4. Two possible mechanisms are assumed to be responsible for such a reduction in $R_{c t}$. First, the formation of a Li-rich layered phase as a nano-domain structure integrated into the outer surface region of the primary particles minimizes a direct oxidation reaction between $\mathrm{Ni}^{4+}$ and electrolyte.[36] Second, the Li-rich layered nano-domains $(\mathrm{C} 2 / \mathrm{m})$ formed inside the 3 layered matrix plays a role like pinning points to prohibit migration and reorganization of the transition-metal ions, which causes phase transition from

3 to 3 (rock-salt) that starts from the particle surface.

\section{Conclusion}

A facile, novel synthesis method, involving only the grinding of the coprecipitated $\mathrm{Ni}_{0.7} \mathrm{Co}_{0.15} \mathrm{Mn}_{0.15}(\mathrm{OH})_{2}$ precursor with $\mathrm{MnCO}_{3}$ and $\mathrm{LiOH} \cdot \mathrm{H}_{2} \mathrm{O}$ and firing at a high temperature, has been developed to obtain high-performance $\mathrm{xLi}_{2} \mathrm{MnO}_{3} \cdot(1-\mathrm{x}) \mathrm{LiNi}_{0.7} \mathrm{CO}_{0.15} \mathrm{Mn}_{0.15} \mathrm{O}_{2}$ cathode materials, It has been found that although the secondary particle size of the $\mathrm{Ni}_{0.7} \mathrm{Co}_{0.15} \mathrm{Mn}_{0.15}(\mathrm{OH})_{2}$ precursor is large $(9 \mu \mathrm{m}$ in diameter on average), the addition of $\mathrm{Mn}$ and thus the 
solid-state diffusion at high temperatures still induces a homogeneous increase in Mn content throughout a whole secondary particle. Furthermore, the additional Mn forms a Li-rich layered phase with $C 2 / m$ symmetry based on the observations of XRD, TEM, and electrochemical charge-discharge measurements. Most importantly, the HRTEM and STEM not only shows the evidence of $C 2 / m$ phase formation, but also reveals the spatial relationship between the conventional 3 layered phase and the newly-formed $C 2 / m$ layered phase. Specifically, the $C 2 / m$ phase exists in relatively-small nano-domain islands embedded into the 3 layered matrix. This is the first straightforward observation of the Li-rich phase formed inside a primary particle with Ni-rich composition. Notably, the resultant $x \mathrm{Li}_{2} \mathrm{MnO}_{3} \cdot(1-\mathrm{x}) \mathrm{LiNi}_{0.7} \mathrm{Co}_{0.15} \mathrm{Mn}_{0.15} \mathrm{O}_{2}$ cathode with optimized $\mathrm{x}$ value combines the advantages of the relatively high capacity from the Ni-rich phase and the high surface chemical stability from the Li-rich phase, leading to superior electrochemical performances with 90 and $81 \%$ of capacity retention, respectively, after 400 cycles at $25{ }^{\circ} \mathrm{C}$ and 200 cycles at 55 o C in half cell, and $73.5 \%$ of capacity retention after 900 cycles in pouch-type full cell. This facile synthesis method sheds light on a smart design of combining Ni-rich and Li-rich layered phases for advanced lithium-ion battery cathodes, which could be easily scaled up for practical, industrial applications.

\section{Acknowledgements}

This work was supported by the Assistant Secretary for Energy Efficiency and Renewable Energy, Office of Vehicle Technologies of the U.S. Department of Energy under Contract no. DE-EE0006447 and Welch Foundation grant F1254. The STEM work was conducted in the William R. Wiley Environmental Molecular Sciences Laboratory (EMSL), a national scientific user facility sponsored by DOE's Office of Biological and Environmental Research and located at PNNL. PNNL is operated by Battelle for the Department of Energy under Contract DE-AC05-76RLO1830. The authors acknowledge the assistance and valuable discussion with Dr. Pilgun Oh and Dr. Jin-Yun Liao.

\section{Reference}

[1] M. Armand, J.M. Tarascon, Nature, 451 (2008) 652-657.

[2] J.B. Goodenough, Y. Kim, Chem. Mat., 22 (2010) 587-603.

[3] M.S. Whittingham, Chem. Rev., 104 (2004) 4271-4301.

[4] A. Manthiram, J.C. Knight, S.-T. Myung, S.-M. Oh, Y.-K. Sun, Advanced Energy Materials, (2015) 1501010. 
[5] H.J. Noh, S.T. Myung, Y.J. Lee, Y.K. Sun, Chem. Mat., 26 (2014) 5973-5979.

[6] J.M. Zheng, W.H. Kan, A. Manthiram, ACS Appl. Mater. Interfaces, 7 (2015) 6926-6934.

[7] J.Y. Liao, A. Manthiram, J. Power Sources, 282 (2015) 429-436.

[8] L.J. Wu, K.W. Nam, X.J. Wang, Y.N. Zhou, J.C. Zheng, X.Q. Yang, Y.M. Zhu, Chem. Mat., 23 (2011) 3953-3960.

[9] J. Li, J. Camardese, R. Shunmugasundaram, S. Glazier, Z.H. Lu, J.R. Dahn, Chem. Mat., 27 (2015) 33663377.

[10] H.J. Noh, S. Youn, C.S. Yoon, Y.K. Sun, J. Power Sources, 233 (2013) 121-130.

[11] C.H. Chen, J. Liu, K. Amine, J. Power Sources, 96 (2001) 321-328.

[12] W. Liu, P. Oh, X. Liu, M.J. Lee, W. Cho, S. Chae, Y. Kim, J. Cho, Angew. Chem.-Int. Edit., 54 (2015) 4440-4457.

[13] Y. Cho, P. Oh, J. Cho, Nano Lett., 13 (2013) 1145-1152.

[14] S.M. Bak, K.W. Nam, W. Chang, X.Q. Yu, E.Y. Hu, S. Hwang, E.A. Stach, K.B. Kim, K.Y. Chung, X.Q. Yang, Chem. Mat., 25 (2013) 337-351.

[15] M.M. Thackeray, S.H. Kang, C.S. Johnson, J.T. Vaughey, R. Benedek, S.A. Hackney, J. Mater. Chem., 17 (2007) 3112-3125.

[16] Z.H. Lu, L.Y. Beaulieu, R.A. Donaberger, C.L. Thomas, J.R. Dahn, J. Electrochem. Soc., 149 (2002) A778-A791.

[17] M. Gu, I. Belharouak, J.M. Zheng, H.M. Wu, J. Xiao, A. Genc, K. Amine, S. Thevuthasan, D.R. Baer, J.G. Zhang, N.D. Browning, J. Liu, C.M. Wang, ACS Nano, 7 (2013) 760-767.

[18] B.H. Song, Z.W. Liu, M.O. Lai, L. Lu, Phys. Chem. Chem. Phys., 14 (2012) 12875-12883.

[19] J.C. Knight, A. Manthiram, Journal of Materials Chemistry A, (2015).

[20] Y.K. Sun, Z.H. Chen, H.J. Noh, D.J. Lee, H.G. Jung, Y. Ren, S. Wang, C.S. Yoon, S.T. Myung, K. Amine, Nat. Mater., 11 (2012) 942-947.

[21] P. Oh, S. Myeong, W. Cho, M.J. Lee, M. Ko, H.Y. Jeong, J. Cho, Nano Lett., 14 (2014) 5965-5972.

[22] M.-H. Choi, C.S. Yoon, S.-T. Myung, B.-B. Lim, S. Komaba, Y.-K. Sun, J. Electrochem. Soc., 162 (2015) A2313-A2318.

[23] A.C. A.C. Larson, R.B. Von Dreele, Los Alamos National Laboratory Report LAUR 86-748 (2004).

[24] A. Boulineau, L. Simonin, J.F. Colin, E. Canevet, L. Daniel, S. Patoux, Chem. Mat., 24 (2012) 35583566.

[25] M. Gu, A. Genc, I. Belharouak, D.P. Wang, K. Amine, S. Thevuthasan, D.R. Baer, J.G. Zhang, N.D. Browning, J. Liu, C.M. Wang, Chem. Mat., 25 (2013) 2319-2326.

[26] K.A. Jarvis, Z.Q. Deng, L.F. Allard, A. Manthiram, P.J. Ferreira, Chem. Mat., 23 (2011) 3614-3621.

[27] Z.H. Lu, D.D. MacNeil, J.R. Dahn, Electrochem. Solid State Lett., 4 (2001) A191-A194.

[28] J. Li, R. Doig, J. Camardese, K. Plucknett, J.R. Dahn, Chem. Mat., 27 (2015) 7765-7773.

[29] D.M. Dai, B. Li, H.W. Tang, K. Chang, K. Jiang, Z.R. Chang, X.Z. Yuan, J. Power Sources, 307 (2016) 665-672.

[30] W.S. Yoon, C.P. Grey, M. Balasubramanian, X.Q. Yang, J. McBreen, Chem. Mat., 15 (2003) 3161-3169.

[31] C.S. Johnson, N.C. Li, C. Lefief, J.T. Vaughey, M.M. Thackeray, Chem. Mat., 20 (2008) 6095-6106.

[32] M. Sathiya, K. Ramesha, G. Rousse, D. Foix, D. Gonbeau, A.S. Prakash, M.L. Doublet, K. Hemalatha, J.M. Tarascon, Chem. Mat., 25 (2013) 1121-1131.

[33] H. Koga, L. Croguennec, M. Menetrier, K. Douhil, S. Belin, L. Bourgeois, E. Suard, F. Weill, C. Delmas, J. Electrochem. Soc., 160 (2013) A786-A792.

[34] M. Sathiya, G. Rousse, K. Ramesha, C.P. Laisa, H. Vezin, M.T. Sougrati, M.L. Doublet, D. Foix, D. Gonbeau, W. Walker, A.S. Prakash, M. Ben Hassine, L. Dupont, J.M. Tarascon, Nat. Mater., 12 (2013) 827-835.

[35] B.H. Song, H.W. Liu, Z.W. Liu, P.F. Xiao, M.O. Lai, L. Lu, Sci Rep, 3 (2013). 
[36] C. Li, H.P. Zhang, L.J. Fu, H. Liu, Y.P. Wu, E. Ram, R. Holze, H.Q. Wu, Electrochim. Acta, 51 (2006) 3872-3883.

\section{Tables}

Table 1. ICP results of $x \mathrm{Li}_{2} \mathrm{MnO}_{3} \cdot(1-x) \mathrm{LiNi}_{0.7} \mathrm{Co}_{0.15} \mathrm{Mn}_{0.15} \mathrm{O}_{2}(\mathrm{x}=0,0.03,0.07$, and 0.10$)$.

\begin{tabular}{cccc}
\hline Sample & Designed formula & Calculated composition & Experimental composition \\
\hline $\mathrm{x}=0$ & $0 \mathrm{Li}_{2} \mathrm{MnO}_{3} \cdot 1.0 \mathrm{LiNi}_{0.7} \mathrm{Co}_{0.15} \mathrm{Mn}_{0.15} \mathrm{O}_{2}$ & $\mathrm{Li}_{1.0} \mathrm{Ni}_{0.7} \mathrm{Co}_{0.15} \mathrm{Mn}_{0.15} \mathrm{O}_{2}$ & $\mathrm{Li}_{1.011} \mathrm{Ni}_{0.694} \mathrm{Co}_{0.150} \mathrm{Mn}_{0.145} \mathrm{O}_{2}$ \\
$\mathrm{x}=0.03$ & $0.03 \mathrm{Li}_{2} \mathrm{MnO}_{3} \cdot 0.97 \mathrm{LiNi}_{0.7} \mathrm{Co}_{0.15} \mathrm{Mn}_{0.15} \mathrm{O}_{2}$ & $\mathrm{Li}_{1.015} \mathrm{Ni}_{0.669} \mathrm{Co}_{0.143} \mathrm{Mn}_{0.173} \mathrm{O}_{2}$ & $\mathrm{Li}_{1.026} \mathrm{Ni}_{0.664} \mathrm{Co}_{0.141} \mathrm{Mn}_{0.169} \mathrm{O}_{2}$ \\
$\mathrm{x}=0.07$ & $0.07 \mathrm{Li}_{2} \mathrm{MnO}_{3} \cdot 0.93 \mathrm{LiNi}_{0.7} \mathrm{Co}_{0.15} \mathrm{Mn}_{0.15} \mathrm{O}_{2}$ & $\mathrm{Li}_{1.034} \mathrm{Ni}_{0.629} \mathrm{Co}_{0.135} \mathrm{Mn}_{0.202} \mathrm{O}_{2}$ & $\mathrm{Li}_{1.039} \mathrm{Ni}_{0.626} \mathrm{Co}_{0.134} \mathrm{Mn}_{0.201} \mathrm{O}_{2}$ \\
$\mathrm{x}=0.10$ & $0.1 \mathrm{Li}_{2} \mathrm{MnO}_{3} \cdot 0.9 \mathrm{LiNi}_{0.7} \mathrm{Co}_{0.15} \mathrm{Mn}_{0.15} \mathrm{O}_{2}$ & $\mathrm{Li}_{1.048} \mathrm{Ni}_{0.6} \mathrm{Co}_{0.129} \mathrm{Mn}_{0.224} \mathrm{O}_{2}$ & $\mathrm{Li}_{1.064} \mathrm{Ni}_{0.589} \mathrm{Co}_{0.126} \mathrm{Mn}_{0.221} \mathrm{O}_{2}$ \\
\hline
\end{tabular}

Table 2. Rietveld refinement results of $x \mathrm{Li}_{2} \mathrm{MnO}_{3} \cdot(1-\mathrm{x}) \mathrm{LiNi}_{0.7} \mathrm{Co}_{0.15} \mathrm{Mn}_{0.15} \mathrm{O}_{2}(x=0,0.03,0.07,0.10,0.20$, and 0.30).

\begin{tabular}{|c|c|c|c|c|c|c|c|c|c|c|c|}
\hline \multirow[b]{2}{*}{ Sample } & \multicolumn{5}{|c|}{3 -like component } & \multicolumn{5}{|c|}{$\mathrm{C} 2 / \mathrm{m}$-like component } & \multirow[t]{2}{*}{$R_{p}$} \\
\hline & $a(\mathrm{~nm})$ & $c(\mathrm{~nm})$ & $\begin{array}{c}\mathrm{Ni} \\
\text { occupancy } \\
\text { at Li site } \\
(\%)\end{array}$ & $\operatorname{Vol}\left(\mathrm{nm}^{3}\right)$ & $\begin{array}{c}\text { Weight } \\
\text { fraction } \\
(\%)\end{array}$ & $a(\mathrm{~nm})$ & $b(\mathrm{~nm})$ & $c(\mathrm{~nm})$ & $\operatorname{Vol}\left(\mathrm{nm}^{3}\right)$ & $\begin{array}{l}\text { Weight } \\
\text { fraction } \\
(\%)\end{array}$ & \\
\hline $\mathrm{x}=0$ & $0.28763(3)$ & $1.4232(1)$ & 2 & $0.10197(3)$ & 100 & & & $-{ }^{a}$ & & & 6.4 \\
\hline$x=0.03$ & $0.28765(4)$ & $1.4234(2)$ & 3.5 & $0.10199(3)$ & 100 & & & $-{ }^{b}$ & & & 7.6 \\
\hline$x=0.07$ & $0.28757(4)$ & $1.4235(2)$ & 2.5 & $0.10194(4)$ & 96.3 & $0.48713(52)$ & $0.87304(68)$ & $0.50632(89)$ & $0.20343(36)$ & 3.7 & 7.9 \\
\hline$x=0.10$ & $0.28692(0)$ & $1.4214(0)$ & 2.5 & $0.10134(1)$ & 91.8 & $0.49182(47)$ & $0.86309(81)$ & $0.50782(52)$ & $0.20228(48)$ & 8.2 & 7.8 \\
\hline$x=0.20$ & $0.28682(1)$ & $1.4219(1)$ & 2.5 & $0.10130(1)$ & 88.6 & $0.49103(44)$ & $0.85346(81)$ & $0.50110(47)$ & $0.19949(20)$ & 11.4 & 9.6 \\
\hline$x=0.30$ & $0.28656(0)$ & $1.4215(0)$ & 2.5 & $0.10109(1)$ & 80.8 & $0.49343(19)$ & $0.85223(23)$ & $0.50371(14)$ & $0.20117(8)$ & 19.2 & 9.9 \\
\hline
\end{tabular}

${ }^{a}$ No $C 2 / m$-like component was present. ${ }^{b}$ Weak peak signal from $C 2 / m$-like component.

Table 3. Summarized values of cycle performance of $\mathrm{xLi}_{2} \mathrm{MnO}_{3} \cdot(1-\mathrm{x}) \mathrm{LiNi}_{0.7} \mathrm{Co}_{0.15} \mathrm{Mn}_{0.15} \mathrm{O}_{2}(\mathrm{x}=0,0.03,0.07$, and 0.10$)$ cathodes.

\begin{tabular}{|c|c|c|c|c|c|c|c|c|c|}
\hline \multirow[b]{2}{*}{ Sample } & \multicolumn{3}{|c|}{$25^{\circ} \mathrm{C}$ and $3.0-4.5 \mathrm{~V}$} & \multicolumn{3}{|c|}{$25^{\circ} \mathrm{C}$ and $3.0-4.6 \mathrm{~V}$} & \multicolumn{3}{|c|}{$55^{\circ} \mathrm{C}$ and $3.0-4.5 \mathrm{~V}$} \\
\hline & $\begin{array}{c}\text { Initial } \\
\text { capacity } \\
\left(\mathrm{mA} \mathrm{h}^{-1}\right) \\
\end{array}$ & $\begin{array}{l}\text { Capacity } \\
\text { retention } \\
(100 \mathrm{~s}, \%) \\
\end{array}$ & $\begin{array}{c}\text { Average } \\
\text { CE (\%) }\end{array}$ & $\begin{array}{c}\text { Initial } \\
\text { capacity } \\
\left(\mathrm{mA} \mathrm{h} \mathrm{g}^{-1}\right) \\
\end{array}$ & $\begin{array}{c}\text { Capacity } \\
\text { retention } \\
(80 \mathrm{~s}, \%)\end{array}$ & $\begin{array}{c}\text { Average } \\
\text { CE (\%) }\end{array}$ & $\begin{array}{c}\text { Initial } \\
\text { capacity } \\
\left(\mathrm{mA} \mathrm{h} \mathrm{g}^{-1}\right) \\
\end{array}$ & $\begin{array}{c}\text { Capacity } \\
\text { retention } \\
(50 \mathrm{~s}, \%)\end{array}$ & $\begin{array}{c}\text { Average } \\
\text { CE (\%) }\end{array}$ \\
\hline$x=0$ & 185 & 78.7 & 98.6 & 204 & 77.7 & 97.3 & 207 & 84.4 & 94.8 \\
\hline$x=0.03$ & 188 & 89.2 & 98.8 & 195 & 80.0 & 98.3 & 213 & 88.9 & 95.8 \\
\hline$x=0.07$ & 189 & 92.4 & 98.9 & 192 & 88.0 & 98.1 & 203 & 90.0 & 95.5 \\
\hline$x=0.10$ & 173 & 94.6 & 99.4 & 183 & 94.5 & 99.6 & 187 & 97.7 & 95.9 \\
\hline
\end{tabular}


Table 4. $R_{s}$ and $R_{c t}$ values from a fitting of Nyquist plots using equivalent circuit.

\begin{tabular}{ccccccccc}
\hline \multirow{2}{*}{ Sample } & \multicolumn{2}{c}{$1^{\text {st }}$ cycle } & \multicolumn{2}{c}{$10^{\text {th }}$ cycle } & \multicolumn{2}{c}{$50^{\text {th }}$ cycle } & \multicolumn{2}{c}{$100^{\text {th }}$ cycle } \\
\cline { 2 - 9 } & $\mathrm{R}_{\mathrm{s}}(\Omega)$ & $\mathrm{R}_{\mathrm{ct}}(\Omega)$ & $\mathrm{R}_{\mathrm{s}}(\Omega)$ & $\mathrm{R}_{\mathrm{ct}}(\Omega)$ & $\mathrm{R}_{\mathrm{s}}(\Omega)$ & $\mathrm{R}_{\mathrm{ct}}(\Omega)$ & $\mathrm{R}_{\mathrm{s}}(\Omega)$ & $\mathrm{R}_{\mathrm{ct}}(\Omega)$ \\
\hline $\mathrm{x}=0$ & 7.4 & 10.3 & 9.1 & 65.8 & 15.2 & 451.7 & 3.4 & 1115.0 \\
$\mathrm{x}=0.03$ & 7.9 & 8.7 & 9.1 & 53.2 & 10.1 & 324.0 & 2.0 & 774.9 \\
$\mathrm{x}=0.07$ & 5.5 & 7.9 & 9.1 & 47.4 & 7.3 & 277.3 & 2.4 & 579.1 \\
$\mathrm{x}=0.10$ & 10.5 & 7.6 & 19.0 & 33.5 & 26.9 & 172.8 & 32.5 & 376.1 \\
\hline
\end{tabular}




\section{Graphical Abstract}

A facile method was developed to integrate a small amount of Li-rich material into Ni-rich material to improve its surface chemical stability. As a result, enhanced cyclability with $73.5 \%$ of capacity retention after 900 cycles in pouch-type full cell at $\mathrm{C} / 3$ has been achieved.

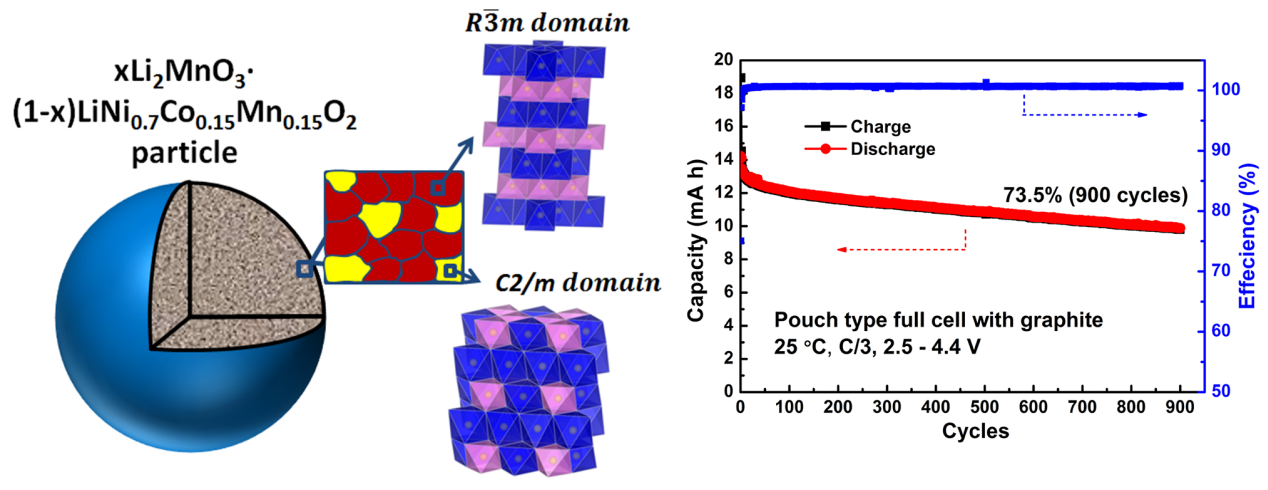

